\title{
The truth, but not yet: Avoiding naïve skepticism via explicit communication of metadisciplinary aims ${ }^{\mathrm{I}}$
}

\author{
Jake Wright, Ph.D. ${ }^{2}$
}

\begin{abstract}
Introductory students regularly endorse naïve skepticismunsupported or uncritical doubt about the existence and universality of truth—for a variety of reasons. Though some of the reasons for students' skepticism can be traced back to the student-for example, a desire to avoid engaging with controversial material or a desire to avoid offense-naïve skepticism is also the result of how introductory courses are taught, deemphasizing truth to promote students' abilities to develop basic disciplinary skills. While this strategy has a number of pedagogical benefits, it prevents students in early stages of intellectual development from understanding truth as a threshold concept. I argue that we can make progress against naïve skepticism by clearly discussing how metadisciplinary aims differ at the disciplinary and course levels in a way that is meaningful, reinforced, and accessible.
\end{abstract}

Keywords: introductory pedagogy, naïve skepticism, student relativism, threshold concepts

\section{I: Introduction}

Introductory students are definitionally novice practitioners assumed to have little or no disciplinary background. Thus, both exposing students to the metadisciplinary aims of the course itself and developing basic academic skills allowing students to

\footnotetext{
${ }^{1}$ Accepted for publication in Teaching in Higher Education

${ }^{2}$ This paper could not have been written without input from a number of my fellow faculty at the University of Minnesota Rochester. Much fruitful discussion about the ways in which naïve skepticism presents itself in non-philosophical courses was provided by Shanna Altrichter, Molly Dingel, James Ford, Aaron Kostko, Brian Mondy, Jennifer Wacek, and two anonymous reviewers.
} 
engage in successful, if basic, disciplinary practice are core focuses of many introductory courses. ${ }^{3}$ These twin goals often come apart for a variety of reasons, including the structural limits imposed on typical university-level courses, preexisting student commitments (Boud and Walker 1990; Delaney 2004; Erion 2005; Irvine 2000; Lewis 2015; Momeyer 1995) and beliefs (Booth 2006; Erion 2005; Land et al. 2005; J. Meyer, Land, and Rust 2003; Momeyer 1995; Satris 1986), pedagogical strategies employed to realize certain aims (Besong 2016; Land et al. 2005), and students' states of intellectual development (Ambrose et al. 20I0; Beebe and Sackris 20I6; Finster 1989; Lochrie 1989; Perry 1970).

Faced with this swirling Charybdis, introductory students often reflexively declare that, at bottom, universal truth does not exist. This unthinking, reflexive rejection of universal truth, which I term naïve skepticism, ${ }^{4}$ is not based on a deep understanding of the nature and value of truth that a more robust skepticism might be based on.

Naïve skepticism has proven distressingly robust, and, as I shall argue below, the way we teach at the introductory level often encourages, rather than discourages, such skepticism. As instructors, we have a duty to move students past naïve skepticism, which interferes with their ability to engage critically not only with core disciplinary concepts, but also the world around them.

${ }^{3}$ See, e.g., discussions by Besong (2016), Burkhard (2017), Cashmore (2015), Momeyer (1995), Stokes (2012), Tait (2012), and Turner (2013).

${ }^{4}$ Naïve skepticism has several names in the existing literature, most often 'student skepticism' after Satris' (1986) original treatment, but also 'reflective relativism' (Momeyer 1995). I use naïve skepticism primarily because it is the naïveté that is problematic, rather than the fact that it is often employed by students or, as a result of the naïveté, employed reflexively. 
I argue that we can make progress on this front via explicit discussion of metadisciplinary goals found both at the course and disciplinary levels, including how these goals intersect and come apart, in a way that is meaningful, regular, and accessible.

My discussion is broadly divided into three parts. First, I discuss the nature of naïve skepticism across the curriculum, including conceptual and developmental challenges faced by students that motivate naïve skepticism, in Section 2. Next, I examine how otherwise justifiable pedagogical strategies encourage naïve skepticism in Section 3 via a case study of introductory philosophy. In Section 4, I present a strategy for overcoming naïve skepticism via a meaningful, regular, accessible discussion of both course and metadisciplinary aims. Finally, I offer brief concluding remarks in Section 5.

\section{2: Naïve skepticism}

Skepticism is the view that truth is non-existent, relative, or unknowable. Skepticism abounds in many disciplines—one can be a skeptic about ethical truths, ${ }^{5}$ religious claims, ${ }^{6}$ the nature of scientific evidence generally (e.g., antirealism) ${ }^{7}$ and specifically (e.g., climate denialism ${ }^{8}$ or rejection of evolutionary theory 9 ), economic principles, ${ }^{\text {Io }}$

\footnotetext{
${ }^{5}$ See, e.g., (Ayer 1952) and (Mackie 1977).

${ }^{6}$ See, e.g., (Schellenberg 2007).

${ }^{7}$ See, e.g., (Cartwright 1983) and (van Fraassen 1980).

${ }^{8}$ See, e.g., Leiserowitz et al.'s (2013) discussion of the effects of Climategate.

${ }^{9}$ See, e.g., (S. Meyer 2009).

${ }^{10}$ See, e.g., (Foster 1997).
} 
historical analysis, ${ }^{\text {II }}$ theories of $a r t,{ }^{12}$ and so forth. It is vital to note, however, that mere skepticism is not, by itself, unreasonable. For many skeptical views, there are well-developed skeptical arguments. Indeed, one of the most broadly skepticial views-Cartesian skepticism, which claims it is impossible to know any fact beyond the contents of one's mind-is taken seriously precisely because of its well-developed arguments. ${ }^{13}$

Such well-developed arguments, however, are generally not the sort introductory students bring with them when voicing skepticism. As Lewis (2015) notes, it would be unusual for introductory students to be capable of articulating such nuanced views. Instead, students often endorse what I call naïve skepticism, a skeptical view in which the underlying arguments are ill-considered or not considered at all. Naïve skepticism represents a 'cluster of phenomena' (Satris I986, I93) that 'fulfils a variety of different functions' (Erion 2005, I29) depending student motivations and intentions. Given the crucial role students' intentions play in the learning process, we should, as Boud and Walker (1990) note, take these motivations into consideration.

\section{I: Naïve skepticism as defensive measure}

Naïve skepticism is frequently deployed as a defense mechanism against views that conflict with core features of students' understanding of their world (Erion 2005; Momeyer 1995; Satris I986; Boud and Walker 1990; Land et al. 2005). There are

\footnotetext{
${ }^{11}$ See, e.g., (Caplan 2013).

${ }^{12}$ See, e.g., Hume's aesthetic skepticism (see [Gracyk 2016] for a review).

${ }^{13}$ See Descartes' Meditations (1998) or (Pollock 1986) for a more intuitive version of the argument.
} 
several reasons why students might deploy such measures, but two in particular bear mentioning here.

First, abandoning skepticism may seem to require a distressing redefinition of both the student and the student's world. Nearly all disciplines introduce threshold concepts — conceptual portals reflecting how disciplinarians think, opening up previously inaccessible ways of thinking about a concept and which often form the core concepts for a discipline (J. Meyer, Land, and Rust 2003). Truth is one such concept; understanding how a discipline engages with truth not only opens up new ways of understanding the world, but is also crucial for successful disciplinary practice.

Threshold concepts are often transformative and troublesome, shifting the learner's view of the world or themselves in a way that is upsetting (J. Meyer, Land, and Rust 2003), making such threshold concepts 'instantly problematic' (Booth 2006, I74). Such redefinition can be so fundamental that there is a corresponding loss of security and one's sense of self (Land et al. 2005). As a result, students can oscillate or become stuck as they work towards understanding a threshold concept (J. Meyer, Land, and Rust 2003; J. Meyer and Land 2005). In disciplines where the nature of truth or the discipline's access to truth seems up for debate, students may retreat towards skepticism to seemingly unassailably avoid engaging with a concept that challenges key features of their worldview. 'I believe $x$,' a student might claim. 'Since there is no universal truth, my belief is secure and you can give me no reason to doubt it.'

The second reason students might reach for naïve skepticism relates to their level of intellectual development. Perry (1970) theorized that student intellectual and ethical development moves through four stages: dualism, a sort of 'we're right, you're wrong' absolutism (Lochrie 1989) where knowledge is handed down by authority 
(Ambrose et al. 20I0); multiplicity, where knowledge becomes merely a matter of opinion and students are unable to differentiate between the strengths and challenges of particular views (Ambrose et al. 20I0); relativism, where knowledge is viewed as contextual and relative (Lochrie I989), evaluated via discipline-specific evidentiary standards (Ambrose et al. 20I0); and commitment, where students at least tentatively commit to a view with the understandings of both the view's challenges and the available alternatives (Ambrose et al. 20I0).

Naïve skeptics can be thought to occupy the multiplicity stage of Perry's framework, while the mature skeptic can be thought to occupy either relativism or the commitment. Indeed, it is their inability or unwillingness to articulate their reasons that place naïve skeptics in the multiplicity camp; if they could evaluate the strengths and weaknesses of their position according to disciplinary standards or articulate why they hold their view despite its challenges and the arguments for alternative views, such skeptics would definitionally no longer be naïve. The naïve skeptic responds as such because they are as yet unable to understand why all views aren't equal; they are missing key threshold concepts that prevent them from moving to the next stage of Perry's framework.

While most first year students, who make up the bulk of introductory students, are dualists, some have moved to multiplicity and some disciplines feature core concepts that are not amenable to dualistic thinking (Finster 1989). In such cases, we should not be surprised when students unthinkingly reach for skepticism because for many students, such skepticism perfectly describes their current developmental state.

\subsection{Naïve skepticism and student ethical commitments}

Students are not empty vessels into which we pour our knowledge. Rather, they arrive with normative beliefs and commitments impacting how they approach the 
world, our courses included. Commonly, these beliefs include a commitment to tolerance and diversity, along with a desire not to offend others (Erion 2005). These beliefs are typically positive features of one's worldview; tolerating difference and avoiding unnecessary offense when we disagree are both important features of liberal, pluralistic societies. One might wonder why we shouldn't therefore be tolerant of all judgements, including judgements of truth. Indeed, naïve skeptics often make this point; extending one's commitment to tolerance is thus a common feature among such skeptics (Delaney 2004; Erion 2005; Irvine 2000; Lewis 2015; Momeyer 1995).

Such commitments and the fear of appearing intolerant or hostile towards diversity are understandable at the introductory level. Boud and Walker (1990) note that presuppositions, anxieties, and fears are more likely in earlier stages of learning like an introductory environment. What the naïve skeptic fails to realize is that tolerance, no matter how well-intentioned or laudable, does not require skepticism about truth. In other words, novice learners' fears are reasonable, but misplaced.

As Finster (1989) notes, no matter where one falls on Perry's framework, there are certain contexts in which dualism remains the appropriate response. Part of moving beyond naïve skepticism involves recognizing both when such circumstances obtain and why commitments to tolerance or a desire to avoid offense can nevertheless remain important. For example, evidence may be unclear, the issue may be unimportant, or one may practice epistemic humility, but none of these features that promote tolerance entail there cannot be a fact of the matter or that the facts are somehow unknowable. Indeed, for some cases of disagreement—for example, whether God exists, whether evolution by natural selection is true, or whether the St. Louis Cardinals have won eleven World Series Championships-one party must be mistaken because each claim purports to describe the way the world is. 


\section{3: The nature of claims promoting naïve skepticism}

Humans, introductory students included, are not relativists about everything. This makes sense, since, as noted above, even those furthest along on Perry's framework recognize that dualistic thinking is sometimes appropriate. Instead, we tend to be relativists about controversial claims for which there is widespread disagreement (Goodwin and Darley 2008, 20I0, 2012; Heiphertz and Young 20I7; Sarkissian et al. 20II). Further, a belief's normative status has powerful effects on one's relativistic view; positively viewed positions are more likely to elicit skepticism, while negatively viewed positions are less likely (Goodwin and Darley 20I2). Again, this makes intuitive sense; as there are some inherently dualistic positions, there are others where dualism seems difficult or impossible. This seems obviously so in cases of widespread normative disagreement. These effects are especially pronounced among individuals in their late teens and twenties—-that is, college-aged individuals - most likely to reject objective beliefs than any other age group (Beebe and Sackris 20I6).

\section{4: Naïve skepticism across the curriculum}

If naïve skepticism is the unthinking or uncritical rejection of objective truth, it is not difficult to see how such skepticism can be present in any discipline, especially those in which the existence or nature of truth is seemingly up for debate. Perhaps some disciplines, like philosophy, are especially prone to naïve skepticism because the discipline is especially interested in the normative, controversial, and unsettled. But as Burkhard notes in his discussion of philosophical naïve skepticism, 'widespread disagreement can be found in other domains, and... normative questions are of course not discussed exclusively in philosophy' (20I7, 30I-2). Such disagreements 
present themselves in a number of ways, both among experts studied by students and among students' peers. ${ }^{14}$

First, there may be agreement on a set of facts or an interpretation of those facts, but disagreement regarding the normative claims we should infer. For example, the data is relatively clear regarding the link between gun ownership and gun deaths (Siegel, Ross, and King 2013), Russian interference in the 2016 U.S. Presidential election (Ohlin 20I7), and anthropogenic climate change (Oreskes 2004), but there is significant disagreement about what we should do about this.

In addition, there are cases where the evidence itself seems unclear or it isn't certain what conclusion we should draw from the evidence. The history student may be asked to investigate the root causes of the American Civil War ${ }^{15}$ or the Rwandan Genocide. ${ }^{16}$ They may be asked to consider whether evolutionary economics accurately describes the world or is merely a useful analogy to help conceptualize certain economic activity. ${ }^{17}$ The physics student may be asked to consider various interpretations of quantum mechanics. The literature student may analyse imagery in Updike's 'A\&P'I8 or Roethke's 'My Papa's Walz.' The economics student may be

${ }^{14}$ I'm grateful to Molly Dingel for her discussion on this point, which helped me conceptualize much of the discussion in this section.

${ }^{15}$ Despite the professional consensus that the American Civil War was caused by slavery, nearly half of Americans believe that the main cause was states' rights (Kohut et al. 2011).

${ }^{16}$ Differing interpretations on the causes of the genocide exist from both the Hutu and Tutsi perspectives (Caplan 2013).

${ }^{17}$ See, e.g., (Foster 1997).

${ }^{18}$ As McFarland notes, the 'continuing attractiveness' of Updike's story lies in its 'ambiguity' $(1983,96)$. 
asked to draw conclusions as to the underlying causes of the 2008 financial crisis or the Great Depression.

Finally, there can be disagreement about the theoretical lens through which the evidence is interpreted. For example, the art history student may be asked to sort through the pros and cons of essentialism and institutionalism. ${ }^{19}$ The sociology student may be asked to interpret educational stratification via technical-functional ${ }^{20}$ and conflict theoretical explanations. ${ }^{2 \mathrm{I}}$

Each of these examples presents a case of widespread, normative disagreement. How we should respond to future crises depends crucially on whether the orthodox or Austrian perspective accurately describes economic behaviour. Whether the Hutu or Tutsi perspective on the Rwandan genocide is accurate may inform how we work to prevent future genocides. Whether the Copenhagen or many-worlds interpretation of quantum mechanics is correct has much to say about how we ought to view our place in the world and the importance of our actions. The imagery in Rothke's poem is vague enough that it is held out as especially well-suited for teaching multiple interpretations (Brown and Garcia Harrison 2000).

Because examples such as these are controversial, normative, and unsettled, they invite conditions that lead to naïve skepticism. Faced with an interpretation of the Civil War that casts the South as explicitly defending slavery may prompt an automatic defensive reaction from a student raised to see the Confederacy as noble and just. Confronting the ambiguity of literary interpretation, where dualistic interpretations seem hard to come by, may cause a dualist or multiplistic student to

\footnotetext{
${ }^{19}$ See, e.g., the debate in (György 1999).

${ }^{20}$ E.g., (Davis and Moore 1945).

${ }^{21}$ E.g., (Collins 1971).
} 
automatically conclude there simply cannot be an underlying fact of the matter.

Students who have not grasped the distinction between truth and justified - though fallible-belief may see potential shortfalls of various economic analyses as ultimately insurmountable and indicative of the absence of an underlying fact. In each case, when naïve skepticism presents itself in the classroom, it presents as students expressing poorly motivated reasons for doubting the discipline's ability to arrive at the truth.

\section{3: How teaching encourages naïve skepticism}

Every discipline has metadisciplinary aims shaping disciplinarians' understanding of what the discipline is, what it tries to accomplish, and how it tries to accomplish its aims. For nearly all disciplines, the search for truth plays a central metadisciplinary role; such disciplines investigate the world in order to provide some truthful account of the way the world is. However, this is not the only goal in truth-seeking disciplines, nor is it the only or central goal of introductory courses, which typically aim at developing skills allowing for successful disciplinary practice.

Traditional pedagogical strategies can inhibit student understanding of threshold concepts (Land et al. 2005). I argue in this section that how we teach students in such courses often encourages naïve skepticism by considering a case study of introductory philosophy teaching and how it can prevent students from understanding philosophy's relation to truth. I do so for two reasons. First, there are few disciplines that place the search for truth in such an explicit, central position. Second, in part because of both the central role the search for truth plays in philosophy and the controversial, unsettled nature of philosophical claims, naïve skepticism has proven especially pernicious in introductory philosophy classrooms. Thus, a great deal of discussion regarding this problem has taken place within philosophy of education literature. By drawing on this literature, it is my hope that 
the problem can be framed clearly enough that nonphilosophers can see their own discipline reflected in the wider themes discussed herein; how the search for truth decouples from the desire to teach basic philosophical skills will, I believe, mirror the divergence of truth and basic disciplinary skills in other disciplines, as well.

As noted, the search for truth is not the only-and often not the primarygoal of philosophy courses. Instead, such courses aim at successfully developing philosophical skills like the ability to understand philosophical concepts, analyse arguments, develop one's views, and engage in philosophical discussion (Besong 20I6; Burkard 20I7). These skills are based on even more rudimentary skillsdistinguishing between types of argument (Turner 2013), argument construction and evaluation (Cashmore 2015), college-level writing (Burkard 2017; Cashmore 2015; Turner 2013) and the development of metacognitive skills (Stokes 2012).

To develop these more basic skills, truth regularly takes a back seat as a matter of pedagogical strategy in introductory courses. Because philosophical questions have a number of persuasive, serious arguments underlying a variety of plausible answers, the standard pedagogical move is to 'teach the debate,' presenting plausible views in their best light without explicitly settling on one view as clearly preferable (Besong 20I6).

Such teaching is analogous to the literature review in peer-reviewed scholarship. For example, scholarship on epistemology, like Plantinga's (I993), standardly has several features, including an overview of the question, a review of the literature, and a positive argument in favour of what the author views as the fact of the matter. Plantinga, for example, does not argue that warranted belief requires proper functioning is a possible position, but rather just is the fact of the matter, accurately describing the nature of knowledge and justified belief. 
It is this advocacy, this view that one is using argumentation to lay bare the facts of the matter, so crucial to successful academic philosophy, that is absent from teaching the debate. Essentially, teaching the debate involves no advocacy and no effort to steer students in one direction or the other. If teaching the debate were an academic article, it would stop after the lit review.

Teaching the debate has several benefits. First, it recognizes instructor/student power dynamics, which can cloud student views by stifling discussion (Tait et al. 2012) or motivating students to uncritically adopt the instructor's view (Besong 2016; Momeyer 1995) in a phenomenon Land et al. (2005) call mimicry; students simply repeat back what they believe they want the instructor to hear and later revert to their original view when agreement with the instructor no longer seems to matter. Such concerns are not hard to find in the literature. For example, Paden laments that his efforts 'failed, for often, later in the semester, I would hear the same [naïvely skeptical] claim advanced in another contextfrequently by one of the better (and more aggressive) students!' (I987, 98) Similarly, Satris observes that 'Perhaps [naïve skepticism's] most disappointing appearance occurs after the course is over, although, mercifully, most instructors are then spared an encounter with it' (1986, 195).

Further, teaching the debate prevents dualistic students from viewing the topic as such by removing the ability for the correct answer to be handed down by an authority figure (Ambrose et al. 20I0). Such transmission of knowledge by authority can prevent students from mastering associated threshold concepts (J. Meyer, Land, and Rust 2003). In addition, this strategy models good philosophical practice via modelling of epistemic humility, allowing instructors to appear 'less biased and thus more objectively rational' (Besong 2016, 403), especially when the instructor is less confident of their view and aware of 'strong, live [alternative] arguments' (404). In 
fact, preventing convergence of opinion—even around a settled view-can be beneficial because such disagreement can lead to fruitful discussion, allowing students to apply the skills they have learned (Gregory 2007).

In short, the instructor allows students to learn good practice by modelling and providing a space for students to engage in good practice. Charitable versions of competing positions are presented and analysed, with the student expected to arrive at their own position via application of tools and methods learned in class. Essentially, students are asked to move along Perry's framework towards either relativism or commitment, while the instructor avoids practices (e.g., declarations of fact in unsettled cases) on the grounds that so doing so interferes with students' philosophical development.

Another way in which our teaching encourages naïve skepticism can be found in the structure of the course itself. Standardly, introductory courses provide a survey of disciplinary content. In the case of philosophy, this typically involves several classic philosophical problems, such as God's existence, the nature of the mind, and the problem of free will. This survey both provides multiple contexts in which students can develop and employ philosophical skills and gives students an idea of disciplinary scope. However, the rapidity with which such units must move, coupled with the novice abilities of introductory students, frequently means that sustained, technical, in-depth discussion is difficult-to-impossible. For example, time and student ability limits discussion of God's existence to one or two readings on each of the major positions, comparatively brief consideration of objections to arguments for each position, and the inevitable move to the next topic.

For someone in the relativism or commitment stages of Perry's framework, teaching the debate within the standard structure of an introductory class can be seen for what it is; a brief presentation of the main claims, advantages, and disadvantages 
of various views on a philosophical topic, repeated from topic to topic. One can adopt a view on a topic while being aware of both that view's flaws and the potential reasonableness of alternative views. One can—and should, provided sufficient justification-adopt such a view as true, even with the caveats just discussed. But students in either the dualism or multiplicity stages can struggle with such discussion (Perry 1970). The dualist will simply yearn for the truth and, if the instructor's pronouncement is not forthcoming, may simply declare that there is no truth (Hood 2006) in a phenomenon Perry terms escape (1970). The student in multiplicity will not see a reason to adopt any view; each unit merely presents a catalogue of the various, equally valid opinions individuals have on a subject. Neither outcome is the goal of actual philosophy, yet this happens with distressing frequency.

As an example of this pull, consider Tait et al.'s (20I2) study of novice philosophy students' view of truth both before and after an introductory course. Though the study was small (n=I8), the results are illustrative. While not all students came into the class believing philosophy did not aim at truth, every single participant left the course with that view. Indeed, several noted their belief that recognizing this 'fact' was a crucial feature of good philosophy. As one participant put it, 'If there were answers, there'd be no point in philosophy lessons" (370).

While additional courses might address this misconception, the majority of introductory students do not take further courses; most are merely fulfilling general education requirements. Thus, the student's view of how philosophy works is profoundly affected by the introductory environment. They do not see what we experts see-tentative steps in search of the truth. Instead, they are overwhelmed by the atmosphere of the class itself, "where opinions and intuitions ply forth to defend themselves in the face of a new confusion or challenge' (Booth 2006, I74), and where 
'the discovery of unresolved debate seems rather to leave students largely emptied of their confidence' (Besong 20I6, 405).

Again, I wish to stress that the problem I consider here is not limited to philosophy. Questions like, 'Why should we care?' 'What should we believe?' 'What theoretical lens should we use?' and 'How should we act in light of our views?' are common across the curriculum. Pedagogical strategies like teaching the debate are either explicitly practiced or have direct analogies in other disciplines, and the reasons for their use mirror those of philosophy; when considering controversial, unsettled, normative claims as a strategy for learning disciplinary skills, such strategies can play an important role in student success. Unfortunately, these strategies also encourage naïve skepticism in students. This is not to say such strategies should be abandoned in philosophy or any other discipline. Rather, as I shall argue in the next section, we have an obligation to supplement these strategies with pedagogical techniques that specifically address naïve skepticism in an effort to minimize its adoption.

\section{4: Overcoming naïve skepticism}

Instructors have long been concerned about students getting stuck in their learning, especially when they get stuck on threshold concepts (Land et al. 2005). Ideally, introductory courses would cover material in a way that allows students to understand why naïve skepticism is inappropriate. Lochrie describes the primary goal of education as 'the imparting of the necessary critical skills of analysis and evaluation to enable students to develop a personal position based on the evidence' $(1989,350)$, which is to say that it is not skepticism that is inherently problematic or that students must abandon it, full stop. It is instead the unreasoned skepticism of the naïve skeptic that must be overcome. 
Unfortunately, this ideal conception of introductory courses collides with practical realities like the academic calendar. We only have so much time to discuss all of philosophy, literature, economics, or any discipline. Concessions must be made, and one of the most common is to eliminate metadisciplinary discussion. For example, as Smith (2017) notes, introductory philosophy courses typically expose students to metaphilosophy in 'a cursory way' (58) if at all; students are provided a brief definition of the discipline on syllabus day with follow-up only in the form of implicit modelling of disciplinary aims and norms throughout the semester.

Such modelling takes place within a multi-layered consideration of disciplinary issues. For example, an introductory ethics course might consider a seemingly straightforward question: Was the U.S. bombing of Hiroshima morally justified? Answering this question requires having a basic view of moral principles, a justification for those principles, and so on, taking a seemingly straightforward question and forcing students to grapple with it on at least three levels-the meta level (what we should value), the normative level (what rules govern our seeking things of value), and the applied level (how the present circumstances interact with moral rules). Because introductory students are not sufficiently sophisticated to suss out the distinction between these levels, we risk negatively impacting our students if we do not communicate what is going on at the metaphilosophical level clearly with them (Ficarrotta 2009).

One of these negative impacts, I have argued, is the encouragement of naïve skepticism. As discussed previously, the creation of this environment is not restricted to a single discipline; similar multi-layered discussions often take place within other disciplines, when considering how to interpret a literary work, evaluating sociological phenomena, and so forth. However, because naïve skepticism is especially pernicious in philosophy, much has been written on this topic from a philosophical 
perspective. Though various prescriptions differ in detail, extant philosophical literature on naïve skepticism converges on a central strategy-directly confront and argue against the naïve skeptic (Hood 2006; Paden 1987, I994; Satris I986; Talbot 2012). Unfortunately, this strategy falls short for two reasons.

First, the strategy recreates the conditions that lead to naïve skepticism; the instructor engages on debate surrounding a threshold concept with profound normative implications the student has not yet understood. From the student's perspective, the nature of truth and our ability to access it are clearly unsettled and controversial, since both student and instructor disagree. In such circumstances, we ought to expect students will retreat to naïve skepticism. If we view truth as a yet-tobe understood threshold concept, students' liminality may cause them to retreat to naïve skepticism as a way of avoiding engagement with the threshold concept. If we view students as dualistic or in multiplicity, they may be primed to either view the professor's arguments as simply wrong or one equally valid opinion among many (Perry 1970). It would be better, as Andreson, Boud, and Cohen (200I) argue, to give students a chance to construct their own meaning, rather than simply browbeat students into submission via one-way transmission of content.

Second, direct engagement ignores a crucial feature of introductory coursestheir goals often differ significantly from the metadisciplinary goals of the disciplines they study. Sophisticated philosophers recognize that metaphilosophical skills, properly developed and deployed, should lead to the discovery of truth, just as properly developed and deployed metaliterary, metamathematical, and metahistorical goals ought to do the same. But, as has been noted, the application and development of these skills can work at cross purposes in the introductory classroom, where the search for truth is deemphasized because the course focuses 
much more on the skill development, rather than the deployment of those developed skills.

Thus, I propose combatting naïve skepticism not by direct frontal assault, but through extended discussion of metadisciplinary aims, including how the aims of an introductory course do not neatly align with these aims. To be successful, this strategy must undermine conditions giving rise to naïve skepticism by moving students away from a defensive posture, addressing prior commitments students bring with them, and/or creating an environment that does not predispose students towards naïve skepticism. Thus, it is not enough to merely confront naïvely skeptical views or engage in merely superficial discussion. The extended discussion I propose must be meaningful, involve regular reinforcement, and be presented accessibly.

\section{I: Meaningful discussion of metadisciplinary aims}

The main feature of my view is that metadisciplinary discussion must be meaningful; it must go into significantly more detail than is typically spent in introductory classes. Most students are unaware of what happens in the classroom in the sense that they are unaware of the reasoning for instructors' pedagogical choices throughout a course; such circumstances can frustrate students (Boud and Walker 1990). Ideally, the course would be organized so that these choices are laid bare in a way that presents metadisciplinary aims and how they relate to the search for truth. Such organization would be especially vital if truth is viewed as a threshold concept. First impressions of threshold concepts matter, and students are more likely to master threshold concepts if they are 'thrown in,' so to speak; avoiding or simplifying threshold concepts in order to ease students in makes understanding the concept more difficult (J. Meyer and Land 2005; J. Meyer and Shanahan 2003). Further, it has been shown that both in-course sequencing and the opportunity to engage with a concept directly and think like a disciplinarian, rather than simply learn how a 
disciplinarian thinks, play a vital role in understanding threshold concepts (J. Meyer and Land 2005).

One option for such organization would be to structure the course as an interrogation of the discipline's purported aims. For example, a philosophy course might start with a metaphilosophy unit discussing both the aims of the discipline generally and how the course will attempt to develop skills that help achieve those aims. A middle section might contain units examining particular philosophical questions in much the way that a standard introductory course might. Finally, the course might conclude with a unit asking students to consider whether, after consideration of these questions, philosophy is able to successfully realize its goal of truth seeking. Such a structure would be analogous to Boud's (1993) Experience Based Learning model on a grand scale, which asks students to prepare, experience, and reflect, with the initial metaphilosophy unit as preparation, the standard middle units as experience, and the final unit as reflection.

Such a structure has several advantages for overcoming naïve skepticism. Most notably, it gives students the opportunity to consider the question of truth in a way that allows them to think like a disciplinarian while also allowing the instructor to continue to teach the debate. Indeed, if the final unit of the course is a reflection on whether-not how-the discipline arrives at truth, the instructor is even able to teach the debate about truth itself. This allows students to receive contextual knowledge, which encourages students to seek and create new knowledge for themselves, rather than merely seek stability (Langer 1993). This mindful learningthat is, learning that allows for novel distinctions (Langer 1993)—contrasts directly with the standard approach of repeating the same arguments against skepticism in a way that does not allow students to question the conclusion of the instructor's argument. Such mindless teaching leads students to 'confuse the stability of [their] 
mind-sets with the stability of the underlying phenomenon' (Langer 2000, 22I), in this case, the student's uncritically accepted skepticism. Instead, a mindful approach like the one sketched above, allows students to consider new information from a position of uncertainty, which makes them ultimately more likely to creatively and spontaneously apply that information (Langer et al. 1989) in a way that can move students past naïve skepticism. Such mindful teaching can allow students to more clearly see the similarities and differences between different things (Langer 1993) like metadisciplinary aims and introductory-level skills.

A structure like this further provides students context, allowing them to see how their prior commitments can be incorporated into a more mature view of truth. For example, as Boud and Walker (1990) note, 'It is common for learners to read their presuppositions into events' (70-7I). Thus, student concerns about their views being attacked, unfairly singled out, or viewed by peers as intolerant—which can lead to naïve skepticism as a defensive response-can be addressed immediately by discussing how and why the discipline takes differing views seriously even in cases of disagreement. Further, as Boud (1993) suggests, prior experience is both the foundation and influence of student learning; we should work with, rather than against, that experience to help students move beyond naïve skepticism. By providing a context in which students can look back on their own experience and reflect on their disciplinary practice, students can better understand their learning experience (Boud and Walker 1990) - in this case, their experience considering the nature of truth itself.

\section{2: Reinforcing metadisciplinary aims}

In addition to meaningful discussion of metadisciplinary aims, it is vital for instructors to regularly reinforce these aims with their students. Introductory courses frequently offer several natural opportunities for such reinforcement. 
One such instance are essays, which allow the chance to reinforce both the aims of the course and the discipline - as well as how they intersect and come apart. For example, a student might be asked to write an essay arguing for theism, atheism, or agnosticism. Because of the nature of the claim at issue, there must be a right answer. Philosophers and theologians believe that the proper application of disciplinary skills will lead us to that truth, and the instructor likely has a reasoned view on this topic, but evaluation of the student's work is based only on the strength of the student's argument relative to the basic skills developed in the introductory course. In other words, the essay is not graded on whether the student has arrived at the fact of the matter, agreed with the instructor's view, successfully applied advanced disciplinary skills, or taken into account the full range of literature on the topic. Given that the instructor will likely want to make these facts known so that students don't feel obligated to write an essay with these features, the essay becomes a natural place where the instructor can revisit and reinforce what the course tries to accomplish and how these goals differ from metadisciplinary aims.

Another opportunity for reinforcement comes in discussion of the topics themselves. At the introductory level, the exploration of any topic is severely constrained by available time and student ability. As a result, nearly all meaningful work on a particular subject is left on the cutting room floor. For example, contemporary epistemology comprises hundreds, if not thousands, of works drawing on decades of increasingly technical attempts to classify the nature of knowledge and rational belief. Introductory students simply lack the technical abilities to interact meaningfully with this work, and the course calendar does not give them sufficient time to develop all of the requisite skills to engage with this literature. Thus, what students frequently encounter is a view that is discussed, objected to in some form, and then dropped as the next view in the sequence is given the same treatment. 
Absent some discussion of why the course operates in this way can give students the impression that each view is fatally flawed and no view represents a plausible candidate for truth. The instructor, however, can fruitfully use such cases to remind students that what takes place in an introductory class is only the beginning of the discussion, rather than the last word on the matter. Objections are not intended to force students to abandon their views, but rather show where work remains to be done, relative to what students have experienced in class. Indeed, for nearly any objection to a view in nearly any discipline, there are serious disciplinarians currently engaged in research intended to address these objections and shortcomings because they view the underlying position as promising.

Finally, the end of each unit provides an opportunity to revisit how the work done by students in that unit allows them to both develop basic skills and-to the extent they are able-practice the discipline in question. Such reflection is crucial for student learning, especially since learners are often unaware of what happens within them (Boud and Walker 1990). For example, each unit might end with an exercise in which students are asked to reflect on their work over the previous sessions and consider how what they have done has made them more able to develop skills and apply them, but also reflect on how the structure of the class or what they did prevented them from seeking truth in the way that a disciplinarian fully engaged in disciplinary practice might. Such a reflection might also ask students to consider what they would have done differently to answer the unit's central question if their context had been different; if they were disciplinarians rather than introductory students, what strategies would they have employed that they either lacked the skills or time to employ? This provides students the opportunity to contextualize and reinforce the idea that what they have done in class may not be a reliable way to 
discover the truth not because the discipline is unable or uninterested, but because their current context is one of basic skill development.

\section{3: Accessible discussion of metadisciplinary aims}

The final feature of this strategy is to ensure that the discussion is presented accessibly. Recall that naïve skepticism is born out of questions that are normative, controversial, and unsettled. Given students' unfamiliarity with many college disciplines - they have likely never taken a formal course in philosophy, sociology, economics, gender studies, etc.—and the college-level focus on critical thinking, as opposed to algorithmic learning, the unsettled nature of many claims introductory courses investigate can make the pull of naïve skepticism especially strong without something familiar for the students to latch onto. Fortunately, a number of metaphors exist that can be deployed to help students understand how the activities in an introductory class can lead to successful practice-that is, the realization of the discipline's metadisciplinary goals_-despite the fact that not all metadisciplinary goals are represented in class. The idea behind these metaphors is simple. If students are able to realize that similar basic practices they are familiar with lead to successfully and fully engaging in a more complex activity despite (and perhaps, because of) their limited scope, they are better positioned to draw similar conclusions about the discipline. In other words, rather than see the pedagogical practices of an introductory class as the full scope of a discipline, students will be more able to see these practices as developing basic skills that, if fully developed, eventually lead to successfully and fully engaging with the discipline and all of its aims.

As an example, the notion of practice or rehearsal might serve as a particularly salient metaphor. Most students are familiar with the notion of practice or rehearsal-either for sports or artistic endeavours like music, theatre, and dance- 
as well as how practice contributes to successfully engaging in an activity without actually constituting successful engagement.

For example, ground ball practice may make one a better baseball player, but ground ball practice does constitute playing baseball. Similarly, musical exercises and drills may make one a better musician by improving fingering, coloratura, et cetera, but do not by themselves constitute successful playing in the typical sense; 'Sweet Child O Mine' notwithstanding, ${ }^{22}$ warmups, exercises, and drills are not generally considered music.

Again, this strategy is not unique to any one discipline. Because the root causes of naïve skepticism are general enough that they arise in any discipline that examines unsettled, controversial, normative claims, a solution that is similarly broad ought to ought to cure what ails us all.

\section{5: Conclusion}

Because of truth's status as a threshold concept, students' relative levels of intellectual development, otherwise successful pedagogical strategies, and the prior commitments students bring with them to class, introductory students are often predisposed to endorse naïve skepticism. Commonly, the response to such skepticism has been to argue directly against it, though this has not proven to be a successful long-term strategy. Instead, I have proposed a strategy of meaningful, regular, accessible discussion of metadisciplinary aims, including how those aims intersect and diverge from specific course aims as a strategy for helping students understand truth as a threshold concept and moving past naïve skepticism.

\footnotetext{
${ }^{22}$ One of the best-known elements of the song — the guitar hook at the beginning — is a stringskipping guitar exercise (Slash and Bozza 2007).
} 
Importantly, my argument is just that-an argument. A natural next step for those who find my argument persuasive would be to study it in a systematic way, to see if the data shows that this strategy ultimately would be successful. Though data is always welcome, I believe I have presented a strong prima facie case for the strategy's usefulness. The tools students learn to use in introductory courses are primed to lead them to truth, but as we must stress throughout the course, those tools won't get the students there just yet.

\section{References}

Ambrose, Susan, Michael Bridges, Marsha Lovett, Michele DiPietro, and Marie Norman. 20I0. How Learning Works: Seven Research-Based Principles for Smart Teaching. Jossey-Bass.

Andresen, Lee, David Boud, and Ruth Cohen. 200I. "Experinece-Based Learning." In Understanding Adult Education and Training, edited by Griff Foley, 2nd ed., 22539. Sydney: Allen \& Unwin.

Ayer, A.J. 1952. Language, Logic, and Truth. New York: Dover.

Beebe, James, and David Sackris. 20I6. "Moral Objectivism across the Lifespan." Philosophical Psychology 29 (6): 9I2-29. http://dx.doi.org/I0.IO80/09515089.20I6.II74843.

Besong, Brian. 20I6. "Teaching the Debate." Teaching Philosophy 39 (4): 40I-I2. https://doi.org/I0.5840/teachphil20I6II2256.

Booth, Jennifer. 2006. "On the Mastery of Philosophical Concepts." In Overcoming Barriers to Student Understanding: Threshold Concepts and Troublesome Knowledge, edited by Jan Meyer and Ray Land, I73-8I. New York: Routledge.

Boud, David. 1993. "Experience as the Basis for Learning." Higher Education Research and Development I2 (I): 33-44. https://doi.org/IO.IO80/0729436930I20IO4.

Boud, David, and David Walker. 1990. "Making the Most of Experience." Studies in Continuing Education I2 (2): 6I-80. https://doi.org/I0.I080/oI58037900I2020I.

Brown, Jean, and Louise Garcia Harrison. 2000. "Reader Responses to Roethke's 'My Papa's Waltz': Exploring Different Perspectives.” In Reader Response in Secondary and College Classrooms, edited by Nicholas Karolides, 2nd ed., 327-38. Mahwah, NJ: Lawrence Erlbaum and Associates.

Burkard, Anne. 20I7. "Everyone Just Has Their Own Opinion: Assessing Strategies for Reacting to Students' Skepticism about Philosophy." Teaching Philosophy 40 (3): 297-322. https://doi.org/I0.5840/teachphil20I7IOI773.

Caplan, Gerald. 2013. "The 1994 Genocide of the Tutsi of Rwanda." In Centuries of Genocide: Essays and Eyewitness Accounts, edited by Samuel Totten and William Parsons, 4th ed., 447-76. New York: Routledge.

Cartwright, Nancy. 1983. How the Laws of Physics Lie. London: Oxford University Press.

Cashmore, Sarah. 2015. "Changing Values in Teaching and Learning Philosophy: A Comparison of Historic and Current Education Approaches." Teaching Philosophy 38 (2): 297-322. https://doi.org/I0.5840/teachphil20I532634. 
Collins, Randall. 197I. "Functional and Educational Theories of Educational Stratification." American Sociological Review 36 (6): I002-I9.

Davis, Kingsley, and William Moore. I945. "Some Principles of Stratification." American Sociological Review IO (2): 242-49.

Delaney, James. 2004. "Tolerance and Tact: A Critical Thinking Strategy for Dealing with Relativism." Inquiry: Critical Thinking Across Disciplines 22 (4): 27-3I.

Descartes, René. 1998. "Meditations on First Philosophy." In Selected Philosophical Writings, translated by John Cottingham, Robert Stoothoff, and Dugald Murdoch, 73-I22. Cambridge: Cambridge University Press.

Erion, Gerald. 2005. "Engaging Student Relativism." Discourse 5 (I): I20-33.

Ficarrotta, J. Carl. 2009. "How to Teach a Bad Ethics Course." Teaching Philosophy 32 (I): 53-68.

Finster, David. 1989. "Developmental Instruction Part I: Perry's Model of Intellectual Development." Journal of Chemical Education 66 (8): 659-6I.

Foster, John. 1997. "The Analytical Foundations of Evolutionary Economics: From Biological Analogy to Economic Self-Organization." Structural Change and Economic Dynamics 8 (4): 427-5I. https://doi.org/Io.IoI6/So954-349X(97)00002-7. Fraassen, Bas van. 1980. The Scientific Image. Oxford: Clarendon Press.

Goodwin, Geoffrey, and John Darley. 2008. "The Psychology of Meta-Ethics: Exploring Objectivism.” Cognition I06: 1339-66. https://doi.org/IO.IoI6/j.cognition.2007.06.007.

—_ - 20I0. "The Perceived Objectivity of Ethical Beliefs: Psychological Findings and Implications for Public Policy." Review of Philosophy and Psychology I: I6I88. https://doi.org/IO.IOO7/si3I64-009-00I3-4. 2012. "Why Are Some Moral Beliefs Perceived to Be More Objective than Others?" Journal of Experimental Social Psychology 48: 250-56. https://doi.org/IO.IOI6/j.jesp.20II.08.006.

Gracyk, Theodore. 20I6. "Hume's Aesthetics." In The Stanford Encyclopedia of Philosophy, edited by Edward Zalta, Summer 2016. https://plato.stanford.edu/entries/hume-aesthetics/.

Gregory, Maughn Rollins. 2007. "A Framework for Facilitating Classroom Dialogue." Teaching Philosophy 30 (I): 59-84.

György, Péter. 1999. "Between and after Essentialism and Institutionalism." The Journal of Aesthetics and Art Criticism 57 (4): 42I-37. https://doi.org/I0.2307/432I49.

Heiphertz, Larisa, and Liane Young. 20I7. "Can Only One Person Be Right? The Development of Objectivism and Social Preferences Regarding Widely Shared and Controversial Moral Beliefs." Cognition 167: 78-90.

Hood, Jane. 2006. "Teaching against the Text: The Case of Qualitative Methods." Teaching Sociology 34 (July): 207-23.

Irvine, William. 200o. "Confronting Relativism." Academic Questions I4 (I): 42-49.

Kohut, Andrew, Carroll Doherty, Michael Dimok, and Scott Keeter. 20II. "Civil War at I50: Still Relevant, Still Divisive." The Pew Center For The People \& The Press.

Land, Ray, Glynis Cousin, Jan Meyer, and Peter Davies. 2005. "Threshold Concepts and Troublesome Knowledge (3): Implications for Course Design and Evaluation." In Improving Student Learning Diversity and Inclusivity, edited by Chris Rust, 53-64. Oxford: Oxford Centre for Staff and Learning Development.

Langer, Ellen. 1993. “A Mindful Education.” Educational Psychology 28I (I): 43-50. https://doi.org/IO.I207/sI5326985ep280I_4. 
—_ 2000. "Mindful Learning." Current Directions in Psychological Science 9 (6): 22023.

Langer, Ellen, Michael Hatem, Jennifer Joss, and Marilyn Howell. 1989. "Conditional Teaching and Mindful Learning." Creativity Research Journal 2 (3): I29-50. https://doi.org/I0.IO80/I04004I89095343II.

Leiserowitz, Anthony, Edward Maibach, Connie Roser-Renouf, Nicholas Smith, and Erica Dawson. 2013. "Climategate, Public Opinion, and the Loss of Trust." American Behavioral Scientist 57 (6): 818-37. https://doi.org/IO.II77/0002764212458272.

Lewis, Court. 2015. "Engaging Student Aversions to Moral Obligations." Teaching Philosophy 38 (3): 273-88. https://doi.org/I0.5840/teachphil20I58II37.

Lochrie, John. 1989. "Perry Revisited-A Fresh Look at Forms of Intellectual and Ethical Development in the College Years." Studies in Higher Education I4 (3): 347-50. https://doi.org/IO.IO80/03075078912331377723.

Mackie, J.L. 1977. Ethics: Inventing Right and Wrong. New York: Penguin.

McFarland, Ronald. 1983. "Updike and the Critics: Reflections on 'A\&P.'" Studies in Short Fiction 20 (2): 95-IOO.

Meyer, Jan, and Ray Land. 2005. "Threshold Concepts and Troublesome Knowledge (2): Epistemological Considerations and a Framework for Teaching and Learning." Higher Education 49: 373-88. https://doi.org/IO.IOO7/sIO734-004-67795.

Meyer, Jan, Ray Land, and Chris Rust. 2003. "Threshold Concepts and Troublesome Knowledge: Linkages to Ways of Thinking and Practising within the Disciplines." In Improving Student Learning: Improving Student Learning Theory and Practice-Ten Years On, I-I6. Oxford: Oxford Centre for Staff and Learning Development.

Meyer, Jan, and Martin Shanahan. 2003. "The Troublesome Nature of a Threshold Concept in Economics." In . Padova, Italy.

Meyer, Stephen. 2009. Signature in the Cell: DNA and the Evidence for Intelligent Design. New York: Harper Collins.

Momeyer, Richard. 1995. "Teaching Ethics to Student Relativists.” Teaching Philosophy I8 (4): 305-II.

Ohlin, Jens David. 20I7. "Did Russian Cyber Interference in the 2016 Election Violate International Law?" Texas Law Review 95: 1579-98.

Oreskes, Naomi. 2004. “The Scientific Consensus on Climate Change.” Science 306: I686. https://doi.org/IO.II26/science.II036I8.

Paden, Roger. 1987. "The Student Relativist as Philosopher." Teaching Philosophy Io (2): 97-IOI.

. 1994. "The Natural History of Student Relativism." The Journal of Thought 29 (2): 47-58.

Perry, William. 1970. Forms of Intellectual and Ethical Development in the College Years: A Scheme. New York: Hold, Rinehart, and Winston.

Plantinga, Alvin. 1993. Warrant and Proper Function. Oxford: Oxford University Press.

Pollock, John. 1986. Contemporary Theories of Knowledge. Savage, MD: Rowman \& Littlefield.

Sarkissian, Hagop, John Park, David Tien, Jennifer Cole Wright, and Joshua Knobe. 20II. "Folk Moral Relativism." Mind \& Language 26 (4): 482-505. https://doi.org/IO.IIII/j.I468-00I7.20II.OI428.x.

Satris, Stephen. 1986. "Student Relativism." Teaching Philosophy 9 (3): 193-205.

Schellenberg, J.L. 2007. The Wisdom to Doubt: A Justification of Religious Skepticism. Ithaca, NY: Cornell University Press. 
Siegel, Michael, Craig Ross, and Charles King. 20I3. "The Relationship Between Gun Ownership and Firearm Homicide Rates in the United States, 198I-20I0." American Journal of Public Health I03 (II): 2098-2I05. https://doi.org/I0.2105/AJPH.2013.30I409.

Slash, and Anthony Bozza. 2007. Slash. New York: HarperEntertainment.

Smith, Renée. 2017. "A Course in Metaphilosophy for Undergraduates." Teaching Philosophy 40 (I): 57-85. https://doi.org/I0.5840/teachphil20I733064.

Stokes, Patrick. 20I2. "Philosophy Has Consequences! Developing Metacognition and Active Learning in the Ethics Classroom." Teaching Philosophy 35 (2): I43-69.

Tait, Gordon, Clare O'Farrell, Sarah Davey Chesters, Joanne Brownlee, Rebecca Spooner-Lane, and Elizabeth Curtis. 2012. "Are There Any Right or Wrong Answers in Teaching Philosophy? Ethics, Epistemology, and Philosophy in the Classroom." Teaching Philosophy 35 (4):367-8I. https://doi.org/I0.5840/teachphil2oI235442.

Talbot, Brian. 20I2. "Student Relativism: How I Learned to Stop Worrying and Love the Bomb." Teaching Philosophy 35 (2): I7I-87.

Turner, Dale. 2013. "How to Teach: Critical Thinking." Teaching Philosophy 36 (4): 3994I6. https://doi.org/I0.5840/teachphil20I3IOI5. 